IRA-International Journal of Technology \& Engineering ISSN 2455-4480; Vol.07, Issue 03 (2017)

Pg. no. 53-61

Institute of Research Advances

http://research-advances.org/index.php/IRAJTE

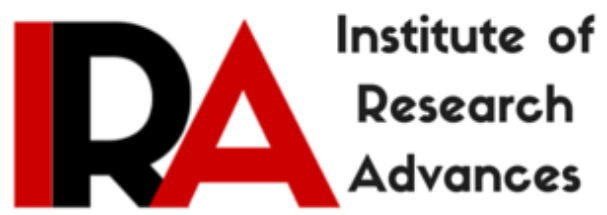

\title{
Performance Evaluation of Evaporative Cooler Using Solar Energy
}

\author{
R.K.Kulkarni ${ }^{1}$, I.H.Patel ${ }^{2}$, R.D.Bothe ${ }^{2}$, P.P.Vyavahare ${ }^{2}$ \\ ${ }^{1}$ TSSM's PVPIT, Bavdhan Pune, India. \\ ${ }^{2}$ SVPM's COE, Malegaon(bk) Tal. Baramati Dist. Pune, India.
}

Type of Reviewed: Peer Reviewed.

DOI: http://dx.doi.org/10.21013/jte.v7.n3.p1

How to cite this paper:

Kulkarni, R., Patel, I., Bothe, R., \& Vyavahare, P. (2017). Performance Evaluation of Evaporative Cooler Using Solar Energy. IRA-International Journal of Technology \& Engineering (ISSN 2455-4480), 7(3), 53-61. doi:http://dx.doi.org/10.21013/jte.v7.n3.p1

(C) Institute of Research Advances

\section{(cc) BY-NO}

This work is licensed under a Creative Commons Attribution-Non Commercial 4.0 International License subject to proper citation to the publication source of the work.

Disclaimer: The scholarly papers as reviewed and published by the Institute of Research Advances (IRA) are the views and opinions of their respective authors and are not the views or opinions of the IRA. The IRA disclaims of any harm or loss caused due to the published content to any party. 


\section{ABSTRACT}

Evaporative cooler operating on solar energy is a viable option in places where there is scarcity of grid power and is also useful for short term storage of farm products. This paper analyzes the performance of a commercial cooler operated on the solar power and its cost benefit analysis. The cooler is operated on grid power in first part and on solar power in second part. The saturation efficiency, cooling capacity and the energy consumption is calculated in both the cases. The efficiency ranged from 41 to $70 \%$, cooling capacity from 4625 to $12079 \mathrm{~kJ} / \mathrm{h}$ and energy consumption from 0.113 to $0.184 \mathrm{~kW}$. The cost benefit analysis gives a payback period of about 11.5 seasons for the cooler if used for only comfort. If the cooler is used continuously for short term storage of farm products, then the payback period is estimated to be of 21.5 months. The optimization of solar panel, battery and inverter cost is suggested to have the early pay back of the investment cost. The cooler installation is recommended in place where there is shortage or frequent fluctuation of grid power.

Keywords: Evaporative Cooler, Solar Energy, Saturation Efficiency, Cooling Capacity, Energy consumption

\section{Introduction:}

Evaporative cooling is the process of adiabatic saturation of air when a spray of water is made to evaporate into it without transfer of heat from or to the surrounding. The initial investment cost of such a system is low and the operation is simple and cheap. The air is sufficiently cooled by evaporative process to result in a considerable summer comfort in climates of high dry-bulb temperature and low relative humidity. Conventional air conditioning system requires high capital investment and its operating costs often become high due to its consumption of electricity. In contrast, evaporative cooling systems provide large energy savings. Thus, a combined use of conventional and evaporative cooling systems can help achieve lower energy consumption which is not possible if standalone conventional cooling system is to be used. Therefore, this method is used for comfort cooling, livestock housing and storage of fruits, vegetables and horticultural produce.

Direct evaporative cooling system uses a fan to pull outside air through media (pads) that are kept wet by water that is sprayed on them (Figure 1). If the outside air is sufficiently dry and hot, the water evaporates on the surface of pads and the heat required for evaporation is taken from air and air is cooled. The dust particles are trapped on the surface of the pad and washed down along with the water. Thus air is filtered and cooled. The water is delivered via tube from a sump tank with the help of a pump. The tank is supplied with tap water whose level may be controlled by a float valve. The resulting fresh, cool, humidified air is blown into the room.

Different researchers have conducted the tests on evaporative coolers with different materials for performance improvement and presented variety of results. Y. Li, R.Z. Wang, [1] reviewed recent progress of solar cooling based on PV panels. They described the main components, configurations, and classifications of systems and also discussed advantages and disadvantages of PV-powered solar cooling systems. Dagtekin et al. [2] conducted the tests on cellulose based cooling pads to study the effect of air velocity on the temperature of air and cooling efficiency. Their results reported that there is no mathematical relation between air velocity, decrease in temperature of air and cooling efficiency. They recommended the air velocity of 0.5 to $1.5 \mathrm{~m} / \mathrm{s}$ through the pad. S. Elmetenania et al. [3] investigated the performance of a direct evaporative air cooler (DEAC) under Algerian climate by simulating the evaporative air cooler for months of June, July and August under TRNSYS environment. They generated measured weather data of the selected site by software and obtained the maximum depression of the DBT at about $18.86^{\circ} \mathrm{C}$ and calculated the EER. They concluded that due to low energy consumption, these 
systems can be powered by solar photovoltaic panels. Kulkarni and Rajput [4] theoretically analysed the performance of jute fiber ropes in the form of rope bank as wetted media in evaporative coolers. They obtained the saturation efficiency values between $57 \%$ and $87 \%$ for different arrangements of rope bank and air mass flow rate between $0.9 \mathrm{~kg} / \mathrm{s}$ and $0.3 \mathrm{~kg} / \mathrm{s}$. Hans-Martin Henning [5] addressed some general issues for using solar thermal energy for air conditioning of buildings. A short overview about the stateof-the-art of available technologies is given and needs and perspectives for future developments are described. Beshkani and Houseini [6] conducted the work on durable corrugated paper as wet media with wetted surface area of $400 \mathrm{~m}^{2} / \mathrm{m}^{3}$ and modelled them. Important parameters affecting the efficiency were studied. Camrago et al. [7] developed a mathematical model of direct evaporative cooler and presented their experimental results with rigid cellulose media having area density of $370 \mathrm{~m}^{2} / \mathrm{m}^{3}$. The performance was measured by saturation effectiveness derived in terms of heat transfer coefficient, air mass flow rate; wetted surface area of cooling media and humid specific heat. Anyanwu [8] designed and tested an evaporative cooler with clay cabinet reinforced with steel wires and coconut fibre as packing material which enhanced water retention capacity of walls. He concluded that performance of such cooler was significantly affected by seasonal weather and it is suitable for short term storage of fresh farm products. Florides et al. [9] examined solar cooling and low energy cooling technologies. They presented brief review of various cooling systems, including solar sorption cooling, solar-mechanical systems, solar related air conditioning, and other low energy cooling technologies. The relative efficiencies and applications of the various technologies are presented.

A large share of the electrical energy is used for space conditioning in residential as well as commercial buildings. This energy consumption can be reduced to some extent by the use of evaporative coolers. Even this energy consumption can be reduced to negligible percentage by the use of solar energy. Evaporative coolers are required for cooling purpose in summer. Solar energy is abundantly available in summer and evaporative cooler operated on solar power, will save this electricity and will be beneficial where there is shortage of electricity.

The evaporative cooler requires electricity for the operation of fan motor and water pump. Normally these units operate on AC electricity. The use of solar energy for evaporative cooler can be made in two ways. One option is to replace these AC motor and pump with DC motor and pump and connect the cooler directly to solar panel that generates enough power for the cooler. In this option the cooler needs to be reassembled and night operation is not possible. Another option is to convert the DC electricity from the solar panel to $\mathrm{AC}$ by using an inverter. In this option, there is no need to replace motor and pump inside the cooler. The cooler can be directly connected to the inverter. Additional equipment like battery, charge controller, and an inverter is needed in this option. This option is more costly but technically it is the more efficient and also allows the cooler to work at night. [10]

\section{Methodology:}

The evaporative cooler commercially available in market is selected for the purpose of this work. The necessary arrangements for the measurement of velocity and temperatures are made at the inlet and the outlet of this cooler. The energy meter is installed to measure energy consumption. In first part of the work the cooler is made to work on the electricity and the necessary observations are taken. The saturation efficiency, cooling capacity and the energy consumption is calculated. In second part of the work, the components required for operation of the cooler on solar power are selected and assembled. The cooler is operated on the electricity generated by the solar panel. The similar set of observations is recorded. The time for testing of the cooler is kept approximately the same as in first part in order to have similar environmental conditions. The saturation efficiency, cooling capacity and the energy consumption is calculated as before. As per the prevailing rates of electricity, the operating cost of cooler on electricity is calculated. The payback period is calculated based on the investment cost incurred for operating the cooler on solar power. 


\section{Experimental set up:}

The experimental set up (Figure 2) consists of commercial desert cooler, solar panel, battery, inverter and necessary instrumentation to carry out the test.

Desert Cooler: Desert cooler available in commercial market is selected for the purpose of testing. The cooler used is evaporative type with dimensions $(\mathrm{LxBxH})=600 \times 290 \times 560$. Its rated power is 185 Watts with air delivery of $1700 \mathrm{~m}^{3} / \mathrm{h}$. The cooler is having the fan, driven by single phase $0.5 \mathrm{HP}$ electric motor having rpm of 1350. The fan is used to suck the air over the cooling pad and deliver it to the room. A reservoir (Sump Tank) is fitted at the bottom of the cooler to store the water required for wetting the pad. The reservoir is replenished with tap water whose level is controlled by a float valve. Capacity of reservoir is 20 lit. A small pump, placed in the reservoir is used for continuous flow of water over the cooling pad. The pump has rated power of $1 / 90 \mathrm{HP}$ and discharge of 7 LPM. Head of the pump is $0.8 \mathrm{~m}$ and it run s at $1300 \mathrm{rpm}$. An extended duct of size $600 \mathrm{~mm}$ by $140 \mathrm{~mm}$ is attached to measure the velocity of air coming out of the cooler.

Solar Panel: Solar panel is selected based on the rated power of the cooler. As rated power of cooler is $184 \mathrm{~W}$. Assuming $6 \mathrm{hrs}$ of operation per day, would require about 1104 or 1200 watt hrs per day. Considering the losses and the availability of panels, $220 \mathrm{~W}, 12 \mathrm{~V}$ monocrystalline solar panel is selected for the purpose.

Battery: The $100 \mathrm{amp} \mathrm{hr} 12 \mathrm{~V}$ battery available in market can store $1.2 \mathrm{~kW}$ of electricity. Hence this battery is chosen for the purpose. Only one battery is sufficient for the set up. [12]

Inverter: The inverter has to produce the required power i.e. 184 watts. A small 12-volt inverter rated at more than this power should be selected so that the higher start-up current of the fan motor is not a problem. A 200-watt inverter integrated with charge controller is selected. [13]

Energy Meter: In order to measure the energy consumed by the cooler, an energy meter is connected. The meter will measure the energy when the cooler runs on either electricity or the solar power. Single phase $240 \mathrm{~V} \mathrm{50Hz}, 5-20$ Amps energy meter having constant of 3200 pulses per kWh, is used.

Temperature Indicator: Digital temperature indicator with 12 channels is used for measurement of dry bulb and wet bulb temperatures at inlet and outlet. The indicator uses iron constantan thermocouples.

All above components of the experimental set up are connected properly to form the complete experimental set up.

\section{Experimental Procedure:}

The experiment is conducted in two parts. In first part, the cooler is operated in normal mode on electric power. The readings of dry and wet bulb temperatures at inlet and outlet, velocity of air at the outlet, time required for 10 pulses of energy meter are recorded. The readings are taken at 3 times in day 9 am, 12 noon and $3 \mathrm{pm}$. Each time the fan speed is varied 3 times and 3 flow rates of air are obtained. The calculations of saturation efficiency, cooling capacity, and energy consumption are done. In second part the cooler is run on electric power from battery and the procedure and all calculations are repeated. The observations for part 1 are recorded in table 1 and the observations for part 2 are recorded in table 3 .

Calculations :- (at 9 am for $1^{\text {st }}$ reading)

1) Power Consumption:-

Power consumed will be maximum when time for 10 pulses of meter is min i.e. 61 secs 
$61 \mathrm{sec}=0.01694 \mathrm{hrs}$

Energy in $k W=\frac{\frac{\text { Pulse }}{\text { Time in } h r s}}{\frac{\text { Pulse }}{k W-h r}}=\frac{\frac{10}{0.01694}}{\frac{3200}{1}}=0.184 \mathrm{~kW}$

Hence Maximum power $=0.184 \mathrm{Kw}$

2) Relative Humidity At Inlet $=42 \%$ for

$\mathrm{DBT} 1=29.4^{0} \mathrm{C} \quad \mathrm{WBT} 1=19.9^{\circ} \mathrm{C}$ from online Psychometric calculator [14]

3) Relative Humidity At Outlet $=57 \%$ for

$\mathrm{DBT} 2=25.5^{\circ} \mathrm{C} \quad \mathrm{WBT} 2=19.4{ }^{\circ} \mathrm{C}$ from online Psychometric calculator [14]

4) Saturation Efficiency $=($ DBT1-DBT2 $) /($ DBT1-WBT1 $) \times 100$

$=(29.4-25.5) /(29.4-19.9)=41.05 \%$

5) Cooling capacity:-

Cooling capacity $=\mathrm{Ma} \times \mathrm{Cp} \times(\mathrm{DBT} 1-\mathrm{DBT} 2) \mathrm{KJ} / \mathrm{hr}$

Volume flow rate of air $=$ Area of duct $\times$ Velocity of air at outlet $=0.14 \times 0.6 \times 3.36$ $=0.28224 \mathrm{~m}^{3} / \mathrm{sec}=1016.064 \mathrm{~m}^{3} / \mathrm{hr}$

Specific volume $=0.861 \mathrm{~m}^{3} / \mathrm{kg}$ for DBT2 $=25.5^{\circ} \mathrm{C} \quad$ WBT2 $=19.4{ }^{0} \mathrm{C}$ from online Psychometric calculator [14]

Mass flow rate of air $=$ Volume flow rate of air $/$ specific volume $=1016.06 / 0.861=1180.10 \mathrm{~kg} / \mathrm{hr}$

Cooling capacity $=\operatorname{Ma} \times \mathrm{Cp} \times(\mathrm{DBT} 1-\mathrm{DBT} 2)=1180.10 \times 1.005 \times(29.4-25.5)=4625.39 \mathrm{~kJ} / \mathrm{hr}$

6) Energy consumption (Assuming 1000 hours of operation in a season i.e. 3 months)

Energy consumption $=1000 \times 0.184=184 \mathrm{Kw}-\mathrm{hr}=184$ Units

The results of the calculations for part 1 are recorded in table 2 and the results of part 2 are recorded in table 4.

Cost benefit analysis :-

Assuming 1000 hours of operation in one season,

1) Operating cost $=1000 \mathrm{hr} \times$ Energy Consumption $\times$ Cost/unit $=1000 \times 0.184 \times 7=1288 \mathrm{Rs}$

$=1300$ Rs Approx.

2) Cost of solar panel, Battery, Inverter $=15000 \mathrm{Rs}$

Pay back period is calculated based on the investment done in operating the cooler on solar power

3) Pay back period $=$ Investment/Operating Cost $=15000 / 1300=11.5$ seasons

This payback period appears to be too long for recovery of the investment cost. In normal house hold applications such period is not justified. So optimization of solar panel, battery and inverter cost is required. Low cost panel, battery and inverter is recommended. However its most important advantage is that can be used where there is shortage of electricity. Another aspect of this approach is that this method can be used for temporary cold storage of farm products before they are dispatched to commercial cold storages. Justification of higher payback period may be in retaining quality of farm products by storing them in such low cost storage for short time. In such application the operation will be continuous and payback period may be calculated by assuming $18 \mathrm{~h}$ operation per day.

Units per day $=0.184 \times 18=3.312 \mathrm{kWh}=3.3$ units

Cost per day $=3.3 \times 7=23.1$ Rs per day

Pay back $=15000 / 23.1=649$ days $=21.6$ months $=22$ months approx.

If power consumption is higher this pay back may be further reduced. 


\section{Conclusion:}

Evaporative cooler can be successfully installed and operated on solar power. The maximum energy consumption of a typical $1700 \mathrm{~m}^{3} / \mathrm{h}$ capacity commercial cooler is $0.184 \mathrm{~kW}$. The saturation efficiency ranges from 41 to $65 \%$ with slightly higher values when operated on solar power. The cooling capacity ranges from 4625 to $8995 \mathrm{~kJ} / \mathrm{h}$ when operated on electricity where as it ranges from 4877 to $12079 \mathrm{~kJ} / \mathrm{h}$ when operated on solar power. The entire range of energy consumption is from 0.113 to $0.184 \mathrm{~kW}$. The maximum reduction in DBT obtained is approx. $9{ }^{\circ} \mathrm{C}$.

The installation of solar operated evaporative cooler for comfort would be beneficial in places where there is scarcity of grid power. Such installation would be also useful in short term storage of farm products before sending them to any commercial cold storage. Cost of installation can be paid back in roughly two years with normal 18 hours operation.

\section{Nomenclature}

DBT1- Dry bulb temperature of air at inlet ${ }^{0} \mathrm{C}$

WBT1-Wet bulb temperature of air at inlet ${ }^{0} \mathrm{C}$

DBT2- Dry bulb temperature of air at outlet ${ }^{0} \mathrm{C}$

WBT2- Wet bulb temperature of air at outlet ${ }^{0} \mathrm{C}$

$\mathrm{Ma}$ - Mass flow rate of air $\mathrm{kg} / \mathrm{h}$

$\mathrm{Cp}$ - Specific heat of air $\mathrm{kJ} / \mathrm{kgK}$

EER- Energy Efficiency Ratio

RH-Relative humidity \%

\section{References}

[1] Li Y., Wang R.Z. (2016). Photovoltaic-powered solar cooling systems, Advances in Solar Heating and Cooling 227-250

[2] Dagtekin M. et al. (2011). The effects of air velocity on the performance of padevaporative cooling systems, African Journal of Agricultural Research, 6, 1813-1822.

[3] Elmetenania S., Yousfi M.L., Merabetia L., Belgrouna Z., Chikouchea A., (2011). Investigation of an evaporative air cooler using solar energy under Algerian climate, Energy Procedia,6, 573-582.

[4] Kulkarni R.K.,\& Rajput S.P.S., (2010). Theoretical performance analysis of jute fiber rope bank as media in evaporative coolers. Indian Journal of Science and Technology, 3(10), 1075-1080.

[5] Henning Hans-Martin , (2007). Solar assisted air conditioning of buildings - an overview, Applied Thermal Engineering,27(10), 1734-1749.

[6] Beshkani, A., \&Hosseini, R., (2006). Numerical modelling of rigid media evaporative Cooler, Applied Thermal Engineering, 26 (5-6), 636-643.

[7] Camargo J.R., Ebinuma C.D., \&Silveria J.L.(2005). Experimental performance of a direct evaporative cooler operating during summer in Brazilian city, International Journal of Refrigeration, 28(7), 1124-1132.

[8] Anyanwu E.E., (2004). Design and measured performance of porous evaporative cooler for preservation of fruits and vegetables, Energy Conversion and Management, 45(13-14), 21872195.

[9]Florides G.A., Tassou S.A., Kalogirou S.A., WrobelL.C. ,( 2002). Review of solar and low energy cooling technologies for buildings, Renewable and Sustainable Energy Reviews,

$6(6), 557-572$

[10] https://www.hunker.com/12447711/how-to-convert-a-swamp-cooler-to-solar-powered

[11]http://www.industrybuying.com/solar-panels-solar-india-SO.PO.1639889/

[12]http://preparednessadvice.com/solar/many-solar-panels-batteries-power-grid-system/

[13] http://www.vispra.com/solar_hybrid_ups.php

[14] online psychometric calculator available at http://www.sugartech.co.za/psychro/index.php 
(Tables \& Figures)

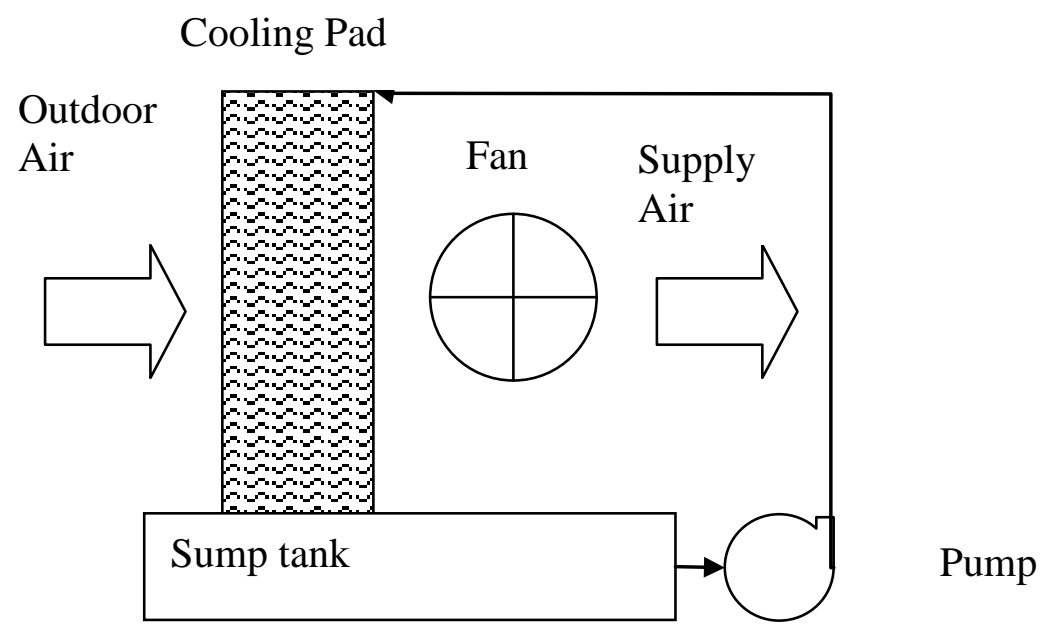

Figure.1.Schematic of direct evaporative cooling system

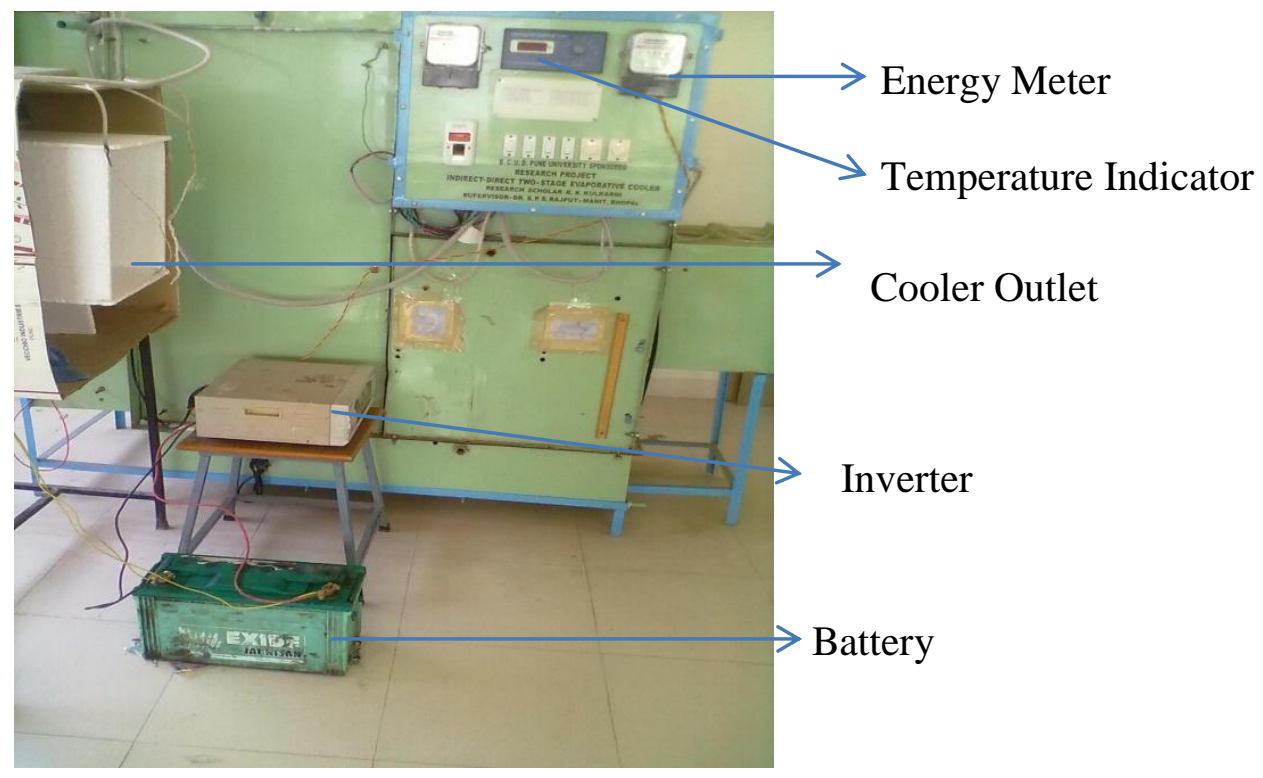

Fig 2. Experimental set up 
Table1. Observations for evaporative cooler running on Electricity

\begin{tabular}{|c|c|c|c|c|c|c|c|}
\hline \multirow[b]{2}{*}{ Time } & \multirow[b]{2}{*}{ Flow } & \multicolumn{2}{|c|}{ Inlet of Cooler } & \multicolumn{3}{|c|}{ Outlet of Cooler } & \multirow[b]{2}{*}{$\begin{array}{l}\text { Time for } \\
10 \text { pulses } \\
\text { of } \\
\text { Energy } \\
\text { Meter } \\
\text { (secs) }\end{array}$} \\
\hline & & $\begin{array}{l}\text { DBT1 } \\
{ }^{\circ} \mathrm{C}\end{array}$ & $\begin{array}{l}\text { WBT1 } \\
{ }^{\circ} \mathrm{C}\end{array}$ & $\begin{array}{l}\text { DBT2 } \\
{ }^{\circ} \mathrm{C}\end{array}$ & $\begin{array}{l}\text { WBT2 } \\
{ }^{\circ} \mathrm{C}\end{array}$ & $\begin{array}{l}\text { Velocity } \\
\mathrm{m} / \mathrm{sec}\end{array}$ & \\
\hline \multirow[t]{3}{*}{$9 \mathrm{am}$} & I & 29.4 & 19.9 & 25.5 & 19.4 & 3.3600 & 61 \\
\hline & II & 29.3 & 20.0 & 25.3 & 19.2 & 3.6750 & 68 \\
\hline & III & 29.5 & 20.2 & 25.5 & 19.0 & 3.9400 & 85 \\
\hline \multirow{3}{*}{$\begin{array}{l}12 \\
\text { noon }\end{array}$} & $\mathrm{I}$ & 29.9 & 22.2 & 25.8 & 19.5 & 3.5500 & 64 \\
\hline & II & 30.2 & 21.8 & 26.1 & 19.3 & 3.6175 & 71 \\
\hline & III & 29.9 & 22.1 & 25.5 & 19.4 & 4.3050 & 84 \\
\hline \multirow[t]{3}{*}{$3 \mathrm{pm}$} & I & 31.9 & 22.4 & 26.2 & 19.5 & 3.4525 & 64 \\
\hline & II & 31.8 & 22.2 & 26.2 & 19.9 & 3.5825 & 70 \\
\hline & III & 32.0 & 22.6 & 25.9 & 19.3 & 4.1825 & 88 \\
\hline
\end{tabular}

Table 2 Results for evaporative cooler running on electricity

\begin{tabular}{|c|c|c|c|c|c|c|c|}
\hline \multirow{2}{*}{ Time } & & \multicolumn{2}{|l|}{ RH } & \multirow[b]{2}{*}{$\begin{array}{l}\text { Sat. } \\
\text { Eff. \% }\end{array}$} & \multirow[b]{2}{*}{$\begin{array}{l}\mathrm{Ma} \\
\mathrm{kg} / \mathrm{hr}\end{array}$} & \multirow[b]{2}{*}{$\begin{array}{l}\text { Cooling } \\
\text { capacity } \\
\mathrm{kJ} / \mathrm{hr}\end{array}$} & \multirow[b]{2}{*}{$\begin{array}{l}\text { Energy } \\
\text { consumption } \\
\mathrm{kW}-\mathrm{hr}\end{array}$} \\
\hline & Flow & $\begin{array}{l}\text { Inlet of } \\
\text { Cooler } \\
\%\end{array}$ & $\begin{array}{l}\text { Outlet of } \\
\text { Cooler } \\
\%\end{array}$ & & & & \\
\hline \multirow[t]{3}{*}{$9.00 \mathrm{am}$} & I & 42 & 57 & 41.05 & 1180.10 & 4625.39 & 0.184 \\
\hline & II & 43 & 57 & 43.01 & 1292.23 & 5194.77 & 0.165 \\
\hline & III & 43 & 54 & 43.01 & 1385.41 & 5569.36 & 0.132 \\
\hline \multirow{3}{*}{$\begin{array}{l}12.00 \\
\text { noon }\end{array}$} & I & 52 & 56 & 53.25 & 1245.38 & 5131.60 & 0.176 \\
\hline & II & 48 & 53 & 48.81 & 1269.06 & 5229.17 & 0.158 \\
\hline & III & 51 & 57 & 56.41 & 1512.00 & 6686.06 & 0.134 \\
\hline \multirow[t]{3}{*}{$3.00 \mathrm{pm}$} & $\mathrm{I}$ & 44 & 54 & 60.00 & 1209.78 & 6930.20 & 0.176 \\
\hline & II & 44 & 56 & 58.33 & 1255.33 & 7064.99 & 0.161 \\
\hline & III & 45 & 54 & 64.89 & 1467.27 & 8995.11 & 0.128 \\
\hline
\end{tabular}


Table 3 Observations for evaporative cooler running on Solar power

\begin{tabular}{|c|c|c|c|c|c|c|c|}
\hline \multirow[t]{2}{*}{ Time } & \multirow[b]{2}{*}{ Flow } & \multicolumn{2}{|c|}{ Inlet of Cooler } & \multicolumn{3}{|c|}{ Outlet of Cooler } & \multirow{2}{*}{$\begin{array}{l}\text { Time for } 10 \text { pulses of } \\
\text { Energy Meter } \\
\text { (secs) }\end{array}$} \\
\hline & & $\begin{array}{l}\text { DBT } \\
{ }^{\circ} \mathrm{C}\end{array}$ & $\begin{array}{l}\text { WBT } \\
{ }^{\circ} \mathrm{C}\end{array}$ & $\begin{array}{l}\text { DBT } \\
{ }^{\circ} \mathrm{C}\end{array}$ & $\begin{array}{l}\text { WBT } \\
{ }^{\circ} \mathrm{C}\end{array}$ & $\begin{array}{l}\text { Velocity } \\
\mathrm{m} / \mathrm{sec}\end{array}$ & \\
\hline \multirow[t]{3}{*}{$9.00 \mathrm{am}$} & I & 33.4 & 22.6 & 27.4 & 22.0 & 3.4523 & 75.76 \\
\hline & II & 31.8 & 22.8 & 27.5 & 22.2 & 3.6850 & 80.71 \\
\hline & III & 32.1 & 22.9 & 27.5 & 21.8 & 3.0350 & 92.96 \\
\hline \multirow[t]{3}{*}{12.00 noon } & $\mathrm{I}$ & 33.3 & 23.6 & 26.5 & 21.0 & 3.0925 & 74.19 \\
\hline & II & 33.9 & 23.8 & 26.8 & 21.7 & 3.3900 & 83.43 \\
\hline & III & 33.5 & 23.5 & 26.7 & 21.5 & 3.6650 & 96.44 \\
\hline \multirow[t]{3}{*}{$3.00 \mathrm{pm}$} & $\mathrm{I}$ & 37.5 & 23.4 & 29.3 & 22.8 & 3.4650 & 72.14 \\
\hline & II & 37.7 & 23.5 & 29.5 & 22.5 & 3.6246 & 80.50 \\
\hline & III & 37.5 & 23.7 & 28.7 & 22.1 & 3.9430 & 100 \\
\hline
\end{tabular}

Table 4. Results for evaporative cooler running on Solar system

\begin{tabular}{|c|c|c|c|c|c|c|c|}
\hline \multirow[t]{2}{*}{ Time } & & \multicolumn{2}{|l|}{ RH } & \multirow[b]{2}{*}{$\begin{array}{l}\text { Sat. } \\
\text { Eff. \% }\end{array}$} & \multirow[b]{2}{*}{$\begin{array}{l}\mathrm{Ma} \\
\mathrm{kg} / \mathrm{hr}\end{array}$} & \multirow[b]{2}{*}{$\begin{array}{l}\text { Cooling } \\
\text { capacity } \\
\mathrm{kJ} / \mathrm{hr}\end{array}$} & \multirow[b]{2}{*}{$\begin{array}{l}\text { Energy } \\
\text { consumption } \\
\mathrm{kW}-\mathrm{hr}\end{array}$} \\
\hline & Flow & $\begin{array}{l}\text { Inlet of } \\
\text { Cooler } \\
\%\end{array}$ & $\begin{array}{l}\text { Outlet of } \\
\text { Cooler } \\
\%\end{array}$ & & & & \\
\hline \multirow[t]{3}{*}{$9.00 \mathrm{am}$} & I & 40 & 63 & 55.56 & 1199.87 & 7235.20 & 0.148 \\
\hline & II & 47 & 65 & 47.78 & 1279.38 & 5528.86 & 0.139 \\
\hline & III & 46 & 61 & 50.00 & 1054.92 & 4876.91 & 0.121 \\
\hline \multirow{3}{*}{$\begin{array}{l}12.00 \\
\text { noon }\end{array}$} & I & 45 & 61 & 70.10 & 1080.05 & 7381.06 & 0.152 \\
\hline & II & 43 & 64 & 70.30 & 1181.03 & 8427.26 & 0.136 \\
\hline & III & 43 & 64 & 68.00 & 1276.84 & 8725.92 & 0.117 \\
\hline \multirow[t]{3}{*}{$3.00 \mathrm{pm}$} & I & 30 & 58 & 58.16 & 1196.14 & 9857.36 & 0.156 \\
\hline & II & 30 & 55 & 57.75 & 1251.37 & 10312.54 & 0.139 \\
\hline & III & 32 & 57 & 63.77 & 1365.82 & 12079.34 & 0.113 \\
\hline
\end{tabular}

Cost Estimation Table

\begin{tabular}{|l|l|l|l|}
\hline Sr.no & Name of item & Quantity & Price(Rs.) \\
\hline 1. & Old Cooler & 1 & 2000 \\
\hline 2. & Solar Panel & 1 & 8000 \\
\hline 3. & Inverter & 1 & 2000 \\
\hline 4. & Battery & 1 & 5000 \\
\hline & & Total & $17000 /-$ \\
\hline
\end{tabular}

